\section{Letter to the Editor: Colonic Perforation}

\section{Carta ao Editor: Perfuração do Cólon}

Keywords: Colon/injuries; Colonoscopy/adverse effects; Intestinal Mucosa/injuries; Intestinal Perforation

Palavras-chave: Cólon/lesões; Colonoscopia/efeitos adversos; Mucosa Intestinal/lesões; Perfuração Intestinal

I read with interest the article titled "Target Sign: Endoscopic Sign of the Colonic Perforation" by Costa $\mathrm{JM}$ et al. ${ }^{1}$ It is indeed unfortunate when a well-intended therapeutic intervention results in iatrogenic complications. Indeed, the early recognition of target sign as a marker of colonic perforation will enable the immediate closure of the defect by endoscopic clips.

The European Society of Gastrointestinal Endoscopy position statement in 2014 recommends clipping either through the scope or over the scope within four hours of colonic perforation, depending on the size of the defect. ${ }^{2}$
Post-procedure, the patients should be admitted and closely observed. If patients remain asymptomatic, they can be discharged with a prescription of oral antibiotics. However, symptomatic patients will require further imaging with computed tomography and possibly even a surgical repair. $^{2}$

As compared to a very high perforation rate of up to $15 \%$ due to acute diverticulitis, colonoscopy related perforation occurs at rates not exceeding $1 \% .{ }^{3}$ Risk factors for colonic perforation includes advancing age, presence of predisposing conditions such as peptic ulcer disease and acute appendicitis, poor nutritional status, the primary cause of the perforation (i.e. either organic versus iatrogenic) and presence of other complications. ${ }^{4}$

Therefore, the need for extra vigilance for complications of therapeutic procedures such as colonoscopy cannot be overemphasized with a proactive search for early signs of bleeding and perforation. ${ }^{5}$ After all, "the eyes can't see what the mind doesn't know."

\title{
REFERENCES
}

1. Costa JM, Soares JB. Target sign: endoscopic sign of the colonic perforation. Acta Med Port. 2017;30:500.

2. Paspatis GA, Dumonceau JM, Barthet M, Meisner S, Repici A, Saunders $B P$, et al. Diagnosis and management of iatrogenic endoscopic perforations: European Society of Gastrointestinal Endoscopy (ESGE) position statement. Endoscopy. 2014;46:693-711.

3. Lohsiriwat V, Sujarittanakarn $\mathrm{S}$, Akaraviputh $\mathrm{T}$, Lertakyamanee $\mathrm{N}$,

Lohsiriwat D, Kachinthorn U. What are the risk factors of colonoscopic perforation? BMC Gastroenterology. 2009;9;1-6.

4. Medscape. Intestinal perforation. [accessed 2017 Aug 13]. Available from http://emedicine.medscape.com/article/195537.

5. Mayo Clinic. Tests and Procedures - Colonoscopy. [accessed 2017 Aug 13]. Available from http://www.mayoclinic.org/tests-procedures/ colonoscopy/basics/risks/prc-20013624.

Navin Kumar DEVARAJ $\square^{1}$

1. Department of Family Medicine. Faculty of Medicine. Universiti Putra Malaysia. Selangor. Malaysia

Autor correspondente: Navin Kumar Devaraj. knavin59@yahoo.com

Recebido: 13 de agosto de 2017 - Aceite: 20 de novembro de 2017 | Copyright @ Ordem dos Médicos 2017

https://doi.org/10.20344/amp.9556
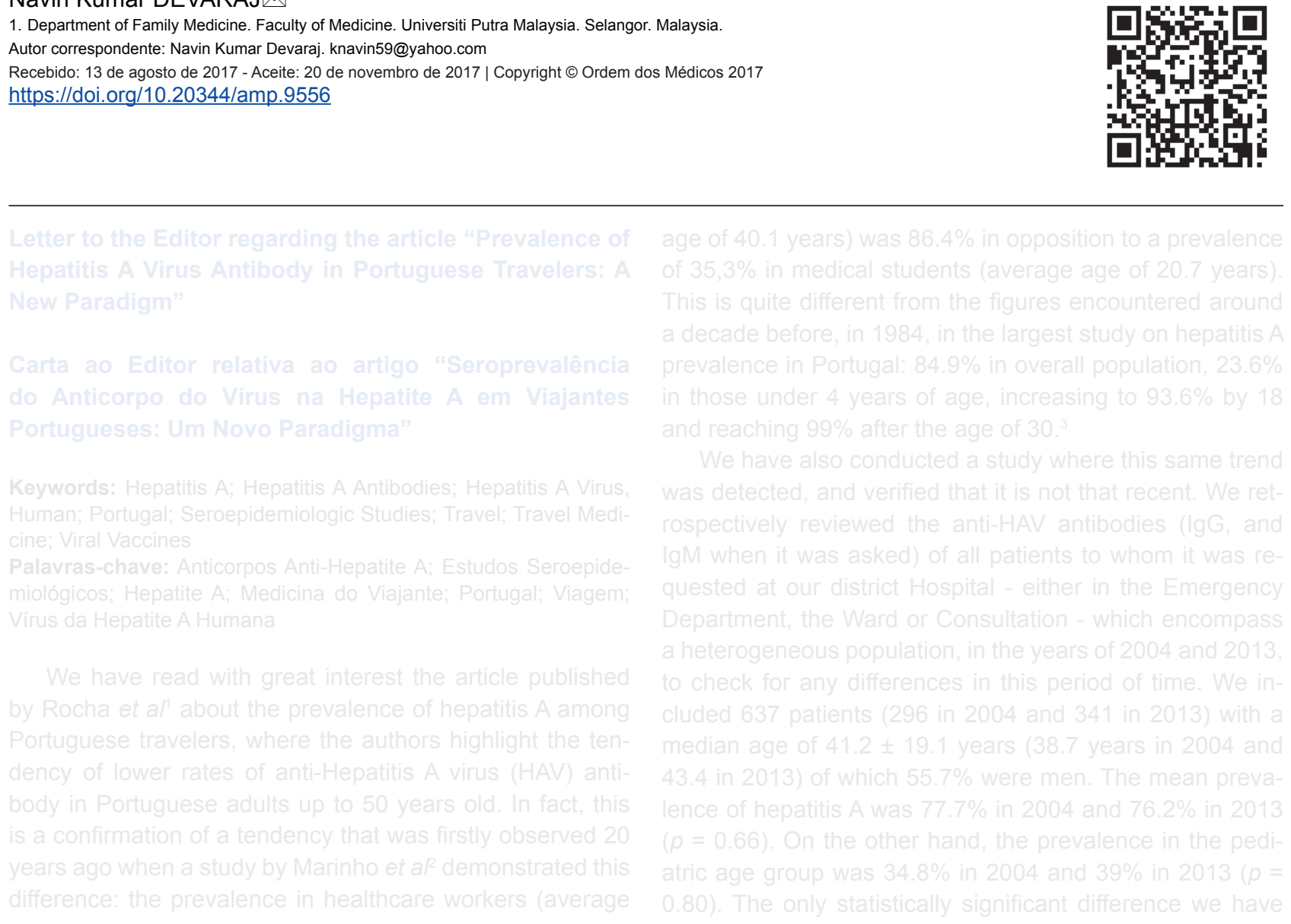